\title{
KAOS HADIS SEBAGAI MEDIA DAKWAH DAN KOMUNIKASI ALTERNATIF
}

\author{
Umi Aflaha \\ Dosen Ilmu Hadis Institut Ilmu al-Quran An-Nur Yogyakarta \\ masghent@gmail.com
}

\begin{abstract}
This article aims to reveals the phenomena of the raise of Hadits or the Da'wah T-shirts based on Hadits of Prophet Muhammad. This observations is in the framework of living Hadith. Further, it will be examined by using the approach of semiotics communication theory of Chalres Sanders Pierce covering the icon, index, and symbol. At this point, this article is expected to explicate comprehensively about the phenomena and ignite communication creation in wider Islamic preaching without tension of diverse perception.
\end{abstract}

Keywords: Hadits, charles sander pierce, semiotics

\begin{abstract}
Abstrak
Artikel ini ingin melihat mengungkap bagaimana maraknya kaos hadis atau kaos dakwah yang berlandaskan pada hadis-hadis Nabi Muhammad saw. Pengamatan fenomena ini dalam kerangka living hadis, kemudian akan dikaji dengan menggunakan pendekatan teori semiotika komunikasi Chalres Sanders Pierce yang meliputi ikon, indeks, dan simbol. Dari sini diharapkan tulisan ini mampu memberikan penjelasan secara komprehensif tentang adanya fenomena tersebut, dan memantik kreasi komunikasi dalam dakwah Islam yang lebih luas tanpa tensi dalam memandang ragam persepsi.
\end{abstract}

Kata Kunci: Kaos hadits, charles sander pierce, semiotika 
INJECT: Interdisciplinary Journal of Communication, Vol.2, No.2, Des. 2017: h. 247-274

\section{Pendahuluan}

Dalam mengarungi perjalanan kehidupan dunia, manusia dianugerahi Allah dua pegangan utama, yaitu al-Quran dan hadis. Maka, barang siapa yang berpegang pada keduanya akan memperoleh keselamatan di dunia maupun di akhirat. Demikian sabda Nabi saw. Kedua hal ini lalu menjelma menjadi perilaku, ajaran, dan rujukan utama dalam keseharian umat Islam. Meski diwarnai perbedaan dalam memahami dan aplikasi dari nilai-nilai yang terkandung di dalamnya, tetapi secara umum mereka sepakat bahwa kedua hal tersebut saling melengkapi satu sama lain. Hadis menjadi penjelas al-Quran dari problematika ketuhanan sampai permasalahan keummatan.

Sebagai secondary source setelah al-Quran, hadis juga menjadi satu acuan yang dihayati dalam keseharian umat Islam. Hadis menjadi jargon yang diyakini memberikan dampak positif yang mampu merubah jalan kehidupan manusia. Karena ia bersumber dari manusia pilihan yang tak pernah tenggelam oleh zaman. Tutur kata dan perilakunya menjelma tiruan manusia. Ia senantiasa diingat dan diteladani sekaligus menjadi kerinduan dalam rapalan shalawat kepadanya. Bahkan umat Islam berlomba-lomba agar seluruh hidupnya, bahka konsep pemikiran dan penghayatan dalam kehidupan sosial hingga persoalan politik-kenegaraan diadopsi sedemikian rupa demi meraih kemiripan bersama Sang Nabi.

Penghayatan akan ungkapan Nabi saw di satu sisi menjadi ekspresi kecintaan kepadanya. Penghayatan tersebut juga bisa berwujud pemahaman dan pengamalan esensi dari ungkapan Nabi. Namun, ada pula penghayatan dalam bentuk komunikasi non verbal melalui beragam simbol pada berbagai media. Yang terakhir ini sekaligus menjadi ekspresi individu maupun kelompok dalam merepresentasikan nilai-nilai religius yang tak berbeda dengan ungkapan verbal. Terlebih di era milenial saat ini, dakwah untuk mengomunikasikan nilai-nilai religius dalam beragam bentuk apa pun seakan tidak ada batasnya. Satu tulisan maupun ujaran 
(speech) dalam satu waktu dapat melesat ke berbagai ruang privat individu, dan dengan segera menuai tanggapan semua kalangan, tak terkecuali hadis Nabi saw.

Tanpa disadari, perlahan tapi pasti, dakwah pun mengalami beragam eksplorasi yang tidak terbatas pada penyampaian secara oral, tapi lewat tulisan. Tulisan telah menjadi elemen penting yang membawa satu pesan dan ideologi tertentu. Ada maksud di balik tulisan, ada pesan yang tersampaikan, dan ada kesan yang melekat bagi orang-orang yang menghayatinya. Ragam media yang semula tak terpikirkan, kini telah menjadi sasaran, salah satunya melalui media kaos.

\section{Hadis dan Media Digital}

Pada awal penyebarannya, hadis Nabi saw mengalami polemik antara proses tulis atau cukup melalui oral. Memang, tradisi yang hidup saat itu adalah tradisi oral, namun tidak berarti menunjukkan absennya seorang juru tulis. Hal ini sebagaimana dikatakan oleh Musthafa A'zami bahwa penulisan hadis telah dimulai sejak masa awal Islam atau saat Nabi masih hidup. Ia mencatat setidaknya ada lima puluh sahabat, empat puluh delapan tabi'in, pada abad pertama Hijriah, delapan puluh enam akhir abad pertama dan awal abad kedua, dan dua ratus lima puluh enam di awal abad kedua. Mereka semua adalah orang-orang yang telribat dalam kegiatan tulis menulis (Amin, 2009:134). Meskipun pernyataan A'zami menuai beberapa kritik dari para kritikus Barat.

Jika ditelusuri sebelumnya, polemik ini merever pada salah satu hadis Nabi yang melarang tentang penulisan hadis Nabi saw yang berbunyi: La taktubu anni, waman yaktubu anni ghair al-Quran fal yamhuhu, yang artinya "janganlah kalian menuliskan sesuatu dariku selain alQuran. Dan barang siapa menulis selain al-Quran maka hendaknya ia menghapusnya (Masrur, 2012:1). Meski demikian, seiring berjalannya waktu, penulisan hadis terus berjalan di kalangan sahabat walaupun tanpa 
ada perintah dari siapa pun. Puncaknya pada masa Umar bin Khattab (w. $23 \mathrm{H} / 644 \mathrm{M}$ ) mulai tebersit ide-ide penulisan hadis, namun belum terlaksana karena Umar khawatir fokus umat Islam dalam mempelajari al-Quran terganggu (Ismail, 1995: 49).

Penulisan hadis secara resmi baru terlaksana pada masa pemerintahan Umar bin Abdul Aziz (w. 101 H/720 M) yang ditujukan kepada Abu Bakar bin Muhammad bin Amr bin Hazm (w. 117 H/735 H.), Gubernur Madinah, dan Muhammad bin Shalih bin Syihab az-Zuhri (w. 124 H./742 M.), seorang ulama kenamaan di Hijaz dan Syam. Dari sinilah maka hadis semakin tersebar ke berbagai wilayah Islam, dan hadis Nabi dapat terhimpun secara keseluruhan. Para ulama menyusun hadis dengan berbagai metode, tidak hanya penulisan matan hadis, tetapi dilengkapi dengan rangkaian para periwayat yang menyampaikan hadis atau sanad (Ismail, 1995:49).

Dengan terkodifikasinya hadis maka hadis Nabi menjadi sesuatu yang umum yang dapat dikaji materi sekaligus rangkaian para periwayatnya. Namun, beberapa saat sebelum perintah resmi terhimpunnya hadis, telah banyak muncul pemalsuan hadis dengan berbagai motivasi. Syuhudi Ismail mengatakan bahwa pemalsuan hadis Nabi dilatarbelakangi berbagai kepentingan, seperti; (1) politik, (2) ekonomi, (3) golongan (mazhab fiqh maupun teologis), (4) mencari muka kepada penguasa, (5) hidup kezuhudan, (6) daya tarik dalam berdakwah. Demikian pula orangorang yang tidak senang terhadap Islam juga banyak yang memalsukan hadis dengan tujuan merusak Islam dari dalam. Dengan problematika inilah, maka para ulama hadis kemudian menyusun beragam pengetahuan, menciptakan metode dan kaidah, menyusun berbagai istilah, dan membuat metode penelitian sanad dan matan, dalam rangka menyelamatkan otentisitas hadis dari para pemalsu (Ismail, 1995:49).

Pada dasarnya, geliat pengkajian hadis senantiasa berputar mengikuti arus zaman. Di era globalisasi saat ini, ketika hadis nabi dan 
ucapan para ulama telah tersebar luas, juga terjadi lagi peristiwa-peristiwa senada dengan yang terjadi pada masa-masa awal kodifikasi hadis Nabi saw. Seakan apa yang disinyalir pada masa-masa awal kodifikasi hadis mengenai maraknya kepentingan dalam penulisan hadis terulang kembali. Pada saat pemilihan pemimpin misalnya, maka banyak hadis bermunculan demi legitimasi pemimpin yang akan diangkat, terlepas hasilnya jauh panggang dari api. Demikian pula ketika pembangunan sebuah masjid, pesantren, panti asuhan, atau lembaga pendidikan, banyak bermunculan hadis yang berkenaan dengan keutamaan bersedekah dan pembangunan, dan lain sebagainya. Meski semua hadis mengandung nilai-nilai kebaikan, namun tidak sedikit hadis-hadis yang digunakan untuk melancarkan "modus" yang sebaliknya. Atau, ada pula hadishadis yang digunakan berdasarkan kepentingan golongan tertentu untuk mediskreditkan golongan lain yang tidak sejalan. Padahal, banyak sekali perangkat yang harus dipergunakan untuk memahami suatu hadis dalam rangka menghasilkan satu keputusan hukum.

Saat ini, beragamnya media seperti memberi peluang bagi semua pihak untuk melancarkan informasinya seputar hadis Nabi. Kecanggihan teknologi semakin terbuka untuk mendokumentasikan momen baik secara literal maupun visual. Media internet memudahkan setiap orang untuk mengakses hadis dari situs-situs yang secara khusus menyediakan konten hadis Nabi saw juga aplikasi-aplikasi yang secara sengaja dibuat untuk memudahkan setiap orang mengakses hadis-hadis Nabis saw. Beberapa di antara situs hadis yang ternama misalnya, sonnaonline.com dan islamweb. net yang dirilis kerajaan Qatar, atau pusatkajianhadis.com besutan pakar hadis Indonesia Lutfi Fathullah.

Dalam situs-situs tersebut banyak fitur yang menawarkan hadis Nabi dengan berbagai sumber periwayatannya. Termasuk adanya fitur konsultasi keagamaan dan konten kajian keislaman baik untuk orang dewasa maupun anak-anak. Tidak hanya itu, dari situs-situs itu pula 
disediakan berbagai konten program kitab turats dari beragam keilmuan Islam. Sehingga setiap orang bisa mendownload dan mengaksesnya secara offline, tinggal menginstal dan menjalankan di komputer pribadi atau mengunduhnya melalui layanan telepon genggam berbasis android atau ios.

Dalam hal ini, Alfatih Suryadilaga menyatakan bahwa kemajuan teknologi informasi memunculkan berbagai produk baru kajian hadis di media global. Ia juga mencoba mendata beberapa kemajuan produk hadis pada ruang lingkup digital. Contoh paling konkret adalah buku dalam bentuk pdf sebagaimana dalam www.omelketab.net/chm/fiqeh/ sobolelsalam.zip; www.omelketab.net/chm/fiqeh/alawttar.zip; http://islamiccouncil.org/programs/Hadith4.zip; www.omelketab.net/chm/hadith/bokhari. zip; atau dalam $h t t p: / / w w w . s a a i d . n e t / b o o k$. Selain itu, juga terdapat dalam bentuk software tertentu yang digagas oleh individu maupun pemerhati hadis lainnya. Seperti software maktabah syamilah, maktabah alfiyah li assunnah al-nabawiyyah. Demikian pula, ia pun merangkum beberapa artikel kajian hadis di era global dalam bentuk e-journal, software, aplikasi kitabkitab hadis maupun semaraknya berbagai kajian di channel youtube.com. (Fatih, 2004:202).

Kesadaran akan perubahan zaman ini semakin dirasakan oleh umat Islam. Kendati kesadaran ini masih perlu digaungkan untuk merespons perubahan media dari waktu ke waktu. Seperti diungkap oleh Hasyim Muzadi pada salah satu kesempatan di Pesantren al-Hikam, ia mengatakan bahwa tantangan terbesar umat Islam di masa yang akan datang adalah kemauan mentransformasi literasi keilmuan ke digital. Jika ini dilakukan, generasi penerus insya Allah akan selamat (Sanusi, 2017:1).

Dalam arti, umat Islam dan para pengkaji keilmuan Islam, utamanya para cendekiawan muslim harus mulai melakukan transformasi dari cetak ke digital. Dengan ini, maka persebaran akan semakin masif dan 
dapat dirasakan oleh kalangan millenial. Namun demikian, transformasi terus bergulir tak mengenal waktu. Saat ini, literasi digital pun lambat laun mulai ditinggalkan, dan beralih ke visual atau video. Dan ini terbukti dari beberapa situs kajian hadis dari tahun ke tahun semakin tak memiliki pengunjung. Sebut saja sonnaonline.com selama kurun waktu dari tahun 2000 sampai 2017 hanya mendapatkan 7358 pengunjung. Demikin pula beberapa portal berita mainstream sekarang ini sudah mulai melengkapi berita tulisnya disandingkan dengan link video dari konten tersebut. Hasilnya, link video itulah yang justru mengundang banyak penonton dibandingkan pembaca beritanya.

Dalam konteks kajian hadis, telah banyak para ulama dan ahli hadis yang mendokumentasikan kajian mereka dalam bentuk video yang kemudian diunggah di channel youtube.com. Video-video kajian hadis itu pun lalu viral dalam durasi yang relatif pendek dan bisa dinikmati sembari bersantai menjelang waktu-waktu istirahat. Pola seperti ini ternyata mampu mendatangkan penonton yang berjumlah ribuan dalam durasi yang tidak terlalu lama. Misalnya fenomena terbaru kajian hadis seorang ustadz yang kesohor melalui akun youtube.com sepanjang tahun 2017 telah mampu mendatangkan ribuan penonton. Ini membuktikan bahwa tradisi literasi semakin tergeser dengan fenomena visual dalam bentuk video.

Seperti dijelaskan dalam tulisan Muhammad Husein Sanusi, pemilihan media video yang lalu dishare lewat youtube dan facebook adalah pilihan yang sangat tepat. Era kekinian adalah era manusia yang sangat menyukai visual dibandingkan teks naskah atau gambar. Bisa dikatakan video adalah masa depan digital, bahkan ekstrimnya, televisi pun kini sudah mulai terancam dengan keberadaan konten yang tayang di youtube atau media sosial lain yang ada fasilitas videonya (Sanusi, 2017:1).

Saat ini, kecenderungan orang lebih pada menyaksikan tayangan video lewat handphone dibandingkan televisi. Alasannya sederhana, 
video di hand phone bisa difilter sesuai dengan tontonan yang disukai saja, dan waktu menontonnya pun bisa diatur sesuai keinginan. Ini merupakan sesuatu yang tak bisa didapatkan dari tayangan video lewat televisi. Misalnya, ketika seseorang ingin tahu bagaimana cara wudu yang benar, maka mereka akan segera mencarinya di google, dan google bisa mengarahkan pada tayangan-tayangan video dengan durasi waktu yang lebih ringkas dan pendek. Dari sini maka yang paling populerlah yang akan banyak dianut. Konsekwensinya, popularitas di google kadang tanpa memperhitungkan keabsahan sanad atau sumber mutawatir.

\section{Hadis dan Sosial Media}

Sosial media merupakan dua unsur yang disatukan dalam satu aplikasi yang mendukung ajang sosialisasi sekaligus sebagai media informasi, baik sifatnya yang terbatas maupun tak terbatas. Saat ini dan kebanyakan orang menggunakan aplikasi ini adalah facebook, whatsapp, line, path, instagram, linked, flicker, twitter, google plus, dan lain sebagainya. Sementara itu, ada beberapa media sosial yang terjaring dalam situs pribadi seperti blog dan beberapa media mainstream yang menyediakan konten jejaring sosial seperti kompasiana, jpnn, tribunners, dan lain-lain.

Dari pengertian di atas, Michael Cross membuat kesimpulan bahwa media sosial merupakan suatu term yang mendeskripsikan beragam teknologi yang digunakan untuk mengikat orang-orang ke dalam suatu kolaborasi, saling tukar informasi, dan berinteraksi lewat pesan yang berbasis web. Karena sifat internet yang selalu mengalami perkembangan, demikian pula berbagai macam teknologi dan fitur yang tersedia pun tidak luput dari perubahan. Hal ini menjadikan sosial media lebih hypernym dibandingkan sebuah rujukan khusus terhadap berbagai penggunaan atau rancangan (Cross, 2014:2).

Layaknya hot issue yang tak pernah padam, di era digital hadis Nabi kian digandrungi oleh umat Islam. Seakan ada keterpanggilan 
untuk mewacanakan hadis Nabi dalam berbagai lini kehidupan. Geliat keislaman juga semakin semarak ditandai dengan berlimpahnya majelismajelis yang mengkaji hadis Nabi saw. Mereka ingin lebih dekat dalam merefleksikan kecintaan kepada sang junjungan umat Islam. Terlebih hadis-hadis yang bertebaran dalam sosial media yang seakan arusnya tak lagi terbendung.

Ketidakterbendungan arus informasi dan teknologi ini juga memengaruhi berbagai cara pandang umat Islam terhadap hadis. Tulisan demi tulisan perihal nilai-nilai religius yang viral melalui media sosial tanpa disadari telah bercokol dalam benak dan membentuk satu kesadaran baru. Cara pandang dan penafsiran atas dogma-dogma agama pun perlahan mulai merasuk menyatu dengan aktivitas dan kehidupan sosial mereka. Membentuk sikap dan gairah keberislaman semakin kuat di satu sisi, atau abai dan minus konfirmasi di sisi lain.

Era modernitas yang menawarkan kemajuan teknologi seakan memberikan peluang pertukaran informasi yang tidak ada batasnya. Satu sisi memiliki nilai positif dengan cepat dan pesatnya informasi. Di sisi lain, informasi yang beredar hampir-hampir tidak bisa diukur kebenarannya, bahkan cenderung pada kebohongan atau hoax. Maka, di sinilah perlunya kemampuan membaca dan memahami serta analisa berbagai sumber dalam literasi digital. Hal ini seperti ungkapan Gilster, bahwa literasi digital adalah kemampuan untuk memahami dan menggunakan informasi dalam berbagai format dari berbagai sumber yang disajikan melalui komputer. Konsep literasi ini melampaui kemampuan membaca; dan itu selalu berarti kemampuan untuk membaca dengan makna sekaligus memahami. Karena yang demikian ini merupakan tindakan dasar kognisi (Gilster, 1997:1).

Maka dari itu, ada beberapa cara untuk menyikapi hadis yang beredar dalam media sosial ini tidak jauh berbeda dengan cara-cara mengecek hadis seperti telah diungkap oleh para ahli hadis, yaitu melalui 
kriteria keshahihan sebuah hadis; (1) kesinambungan periwayatan; (2) perawi harus adil; (3) semua perawi harus dhabith (kuat hafalannya); (4) isnad dan matan harus bebas dari keraguan (syadzdz); isnad dan matan harus bebas dari kecacatan ('illah) (Suyuti, 1972:63).

Sementara itu, di era sosial media, setidaknya ada empat langkah mudah untuk verifikasi berita sebagaimana diungkap oleh Dimas Fathroen sebagai berikut: Pertama; (1) Ada kata-kata; sebarkanlah! viralkanlah!, (2) artikel penuh dengan huruf besar dan tanda seru, (3) merujuk ke kejadian dengan istilah kemarin, dua hari yang lalu, seminggu yang lalu, tanpa ada tanggal yang jelas, (4) ada link asal berita tapi waktu ditelusuri, beritanya sama sekali beda atau malah link sudah mati. Cek terlebih dahulu link yang ada di info tersebut. Contoh ketika ada berita Sri Mulyani antri Nike Great Sale berjam-jam. Ternyata nama sama, tapi bukan Menkeu, (5) link berita asal merupakan opini seseorang, bukan fakta. Harus diingat, beda opini dan fakta.Coba cari di google tema berita spesifik yang ingin dicek, diikuti dengan kata hoax di belakangnya. Biasanya kalau memang hoax, akan ketemu pembahasannya.

Kedua, coba cari di google tema berita spesifik yang ingin dicek, diikuti dengan kata hoax di belakangnya. Biasanya kalau memang hoax, akan ketemu pembahasannya. Ketiga, ini agak perlu ekstra niat. Kalau ada gambar beserta berita, save gambarnya, kemudian cari gambar sejenis di https://images.google.com/ (harus desktop mode, tidak bisa mobile mode). Kadang ketemu artikel-artikel lain dengan gambar sejenis. Kadang ketemu artikel lama yang sama sekali beda yang memakai gambar yang sama. Cara mencari berdasarkan gambar (searchbyimage) ada di link berikut: https://www.google.com/intl/en-419/insidesearch/features/images/ searchbyimage.html. Keempat, sekarang sudah ada juga aplikasi untuk mengecek hoax: http://hoaxanalyzer.com/ Silakan dicoba dan mari kita bebaskan media sosial dari berita hoax (Fathroen, 2017:1). 


\section{Hadis pada Kaos: dari Literasi ke Media Visual}

Perdebatan dan diskusi tentang hadis tidak saja meramaikan jagad maya. Selain pada media digital dan media sosial, masyarakat millenial, terutama remaja muslim sepertinya tidak rela adanya ruang kosong tanpa syiar, mereka berusaha mengisi ruang-ruang tersebut dengan berbagai "slogan" bermakna. Dalam hal ini penulis mengamati marak-berkembangnya distro-distro muslim yang menjajakan kaos-kaos bertemakan Islam yang bersumber dari al-Quran dan hadis. Teks-teks hadis Nabi saw. diartikan, lalu dituliskan dengan berbagai model disain font dan typeface yang menarik. Hadis-hadis yang semula dianggap sebagai teks sakral kini telah menempel pada kaos. Lebih dari itu menjadikan kaos hadis sebagai bagian dari lifestyle sekaligus komunikasi ideologis bagi pemakainya.

Dilihat dari kaca mata sosiologis, kaos-kaos hadis yang ada di pasaran ini mengikuti geliat keberislaman masyarakat yang semakin semangat menyuarakan Islam. Ini juga tidak lepas dari bagaimana pola dakwah kreatif yang terjadi dalam ruang publik dunia nyata maupun maya. Tren ini juga didasari keinginan untuk menyampaikan satu nilai dari ajaran Islam yang semakin membumi, membidik pasar anak-anak muda muslim. Jika boleh dikaitkan, bisa jadi inilah bentuk dakwah terang-terangan dalam bentuk media visual. Terlebih media internet pada empat tahun ke belakang menjadi arena pemasaran dan jual beli yang cukup menjanjikan. Terlepas dari sisi kepribadian pemakainya, apakah sikap dan tingkah lakunya sesuai dengan nilai-nilai yang tertulis pada kaos tersebut, atau justru sebaliknya, hanya mengenakannya sebagai bentuk show up semata.

Tidak terlalu sulit menemukan kaos-kaos bertemakan hadis Nabi saw. banyak sekali lapak online yang menjajakannya, seperti $h t t p: / / w w w$. kaoshadits.com; http://kaosmuslimprayer.com; https://kaosbapaksholeh. com. https://tees.co.id; http://www.kaosdakwahislami.id. Situs-situs ini 
menjajakan kaos hadis seperti tampak dalam gambar-gambar di bawah ini:
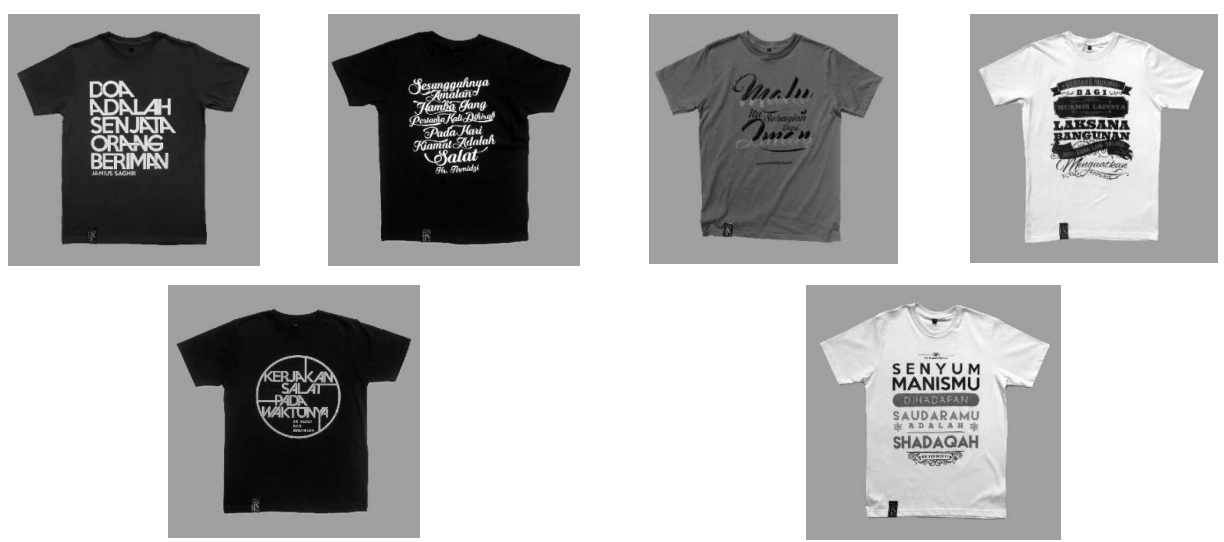

Gambar 1.

Kaos-kaos di atas secara tegas memuat terjemahan hadis-hadis $\mathrm{Nabi}$ saw. Tulisan-tulisan yang tertera telah didisain sedemikian rupa dengan pilihan font dan typeface yang beragam sehingga tampak lebih menawan. Tampak kaos-kaos pada gambar pertama dituliskan terjemahan dari hadis Nabi yang berbunyi "ad-dua silahul mukmini" di mana riwayat tersebut bisa ditemukan dalam kitab al-jami' ash-shaghir dan al-mustadrak 'ala ashshahihain. Pada kaos kedua tertulis kalimat "Sesungguhnya amalan hamba yang pertama kali dihisab pada hari kiamat adalah shalat". Kemudian, kaos berikutnya bertuliskan "Malu itu Sebagian dari Iman" yang merupakan terjemahan dari hadis al-hayau min al-iman. Secara lebih jelas, hadis yang terakhir disebut ini berbicara tentang salah seorang sahabat Nabi yang membully saudaranya disebabkan rasa malunya, dianggapnya perasaan malu tersebut telah merugikannya. Kemudian Rasulullah saw. berkata, "Biarkan dia, karena malu termasuk dari iman".

Selain itu, ada pula yang menyuarakan hadis yang bernada ajakan untuk saling menguatkan sesama muslim dalam ungkapan, "Seorang mukmin bagi mukmin lainnya laksana bangunan satu sama lain saling menguatkan". Juga memberikan peringatan untuk memperhatikan 
waktu shalat yang berbunyi, "kerjakan shalat pada waktunya". Demikian pula ajakan untuk selalu bersedekah walaupun dengan senyuman dalam kalimat, "senyumanmu di hadapan saudaramu adalah shadaqah". Uniknya, dan mungkin menjadi nilai positif, kaos-kaos di atas tetap menuliskan sumber riwayat dari kutipan hadis. Sumber riwayat ditulis secara terpisah, dan terkadang dengan bentuk font yang berbeda dan lebih kecil.

Lain halnya dengan kaos di atas, kaos-kaos pada gambar berikutnya bertuliskan kalimat-kalimat yang sekadar mengambil spirit dari petuah Nabi, seperti terlihat di bawah ini:
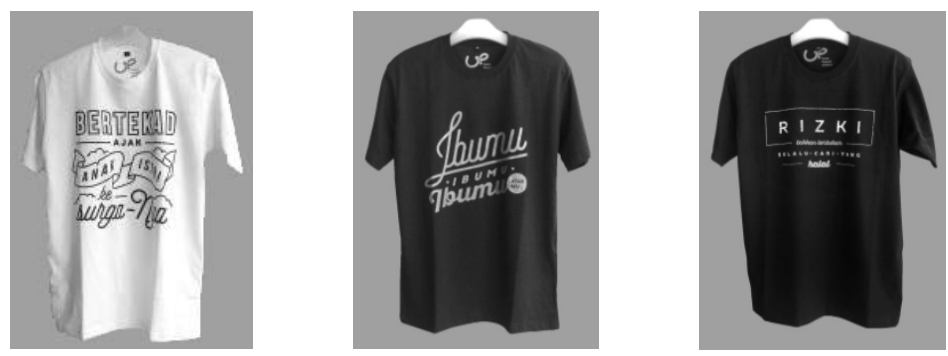

Gambar 2.

Pada kaos pertama tertuliskan "bertekad ajak anak istri ke surgaNya". Secara sekilas, susunan kalimat dalam kaos tersebut bukanlah susunan dari hadis Nabi saw. Akan tetapi, jika boleh dihubungkan maka akan ditemukan banyak sekali hadis yang menyuarakan untuk mengajak anak istri ke surga. Bisa jadi spirit ini mengambil dari al-Quran surat atTahrim ayat 6 , yang memberikan isyarat kepada orang-orang beriman untuk menyelamatkan diri dan keluarga dari api neraka. Dari ayat ini bisa ditarik kesimpulan bahwa sebagai kepala keluarga seorang ayah memiliki kewajiban untuk bertekad menyelamatkan anak dan istri dari api neraka. Sebaliknya, para ayah juga harus mempunyai tekad untuk membawa mereka ke surga. Tentu pernyataan ini didukung dengan banyaknya hadis tentang pentingnya pendidikan agama untuk keluarga; anak dan istri. Atau, bisa juga merujuk pada al-Quran surat Ath-Thur [52]: 21. Mengenai kebahagiaan dan kenikmatan puncak para penghuni 
surga adalah ketika mereka dihubungkan dengan keturunan mereka di surga.( Ibnu Katsir, tt:432).

Menarik mengamati tulisan di kaos no. 2, pada gambar ke-2 di atas, "Ibumu, ibumu, ibumu; baru ayahmu". Ini merupakan simplikasi dari hadis perintah untuk mendahulukan kebaktian kepada ibu dengan tiga kali penyebutan, kemudian ayahmu. Hadis ini tidak sulit dicarikan referensinya (al-Bukhori, tt: 5514). Selain dari situs-situs tersebut, hadis pada kaos di bawah ini sedikit berbeda dari sebelumnya, karena telah menggunakan beberapa ilustrasi yang dipadukan dengan bentuk font dan typeface yang beragam.
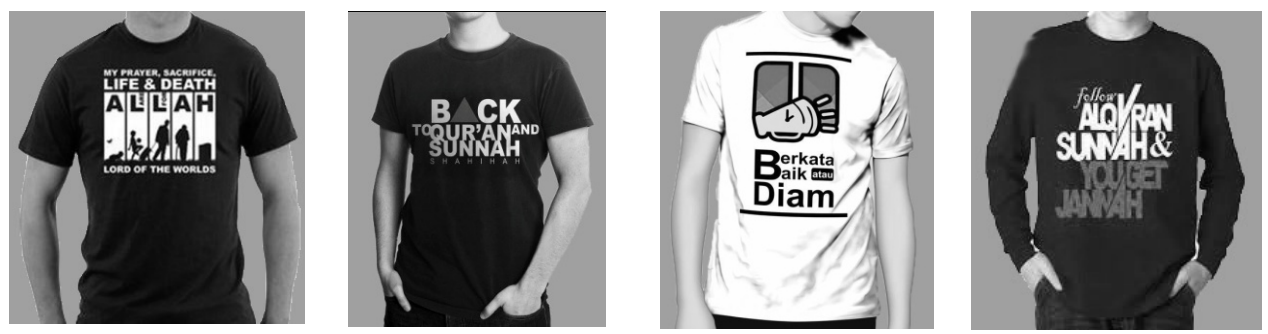

Gambar 3.

Pada dasarnya tidak jauh berbeda dengan lainnya, kaos-kaos ini bernada untuk mengingatkan para pembaca akan berbagai hal. Namun ada perbedaan dengan sebelumnya, kaos-kaos pada gambar ke-3 tidak hanya menampilkan bentuk komunikasi literal, tetapi sudah mulai merambah komunikasi visual, terutama permainan media grafis, termasuk media visual yang menyajikan fakta, ide, atau gagasan melalui penyajian kata-kata, kalimat, angka-angka, dan simbol atau gambar. Seringkali ini digunakan untuk menarik perhatian, memperjelas sajian ide, dan mengilustrasikan fakta-fakta sehingga menarik dan diingat orang (Susilana, 2009:14). 

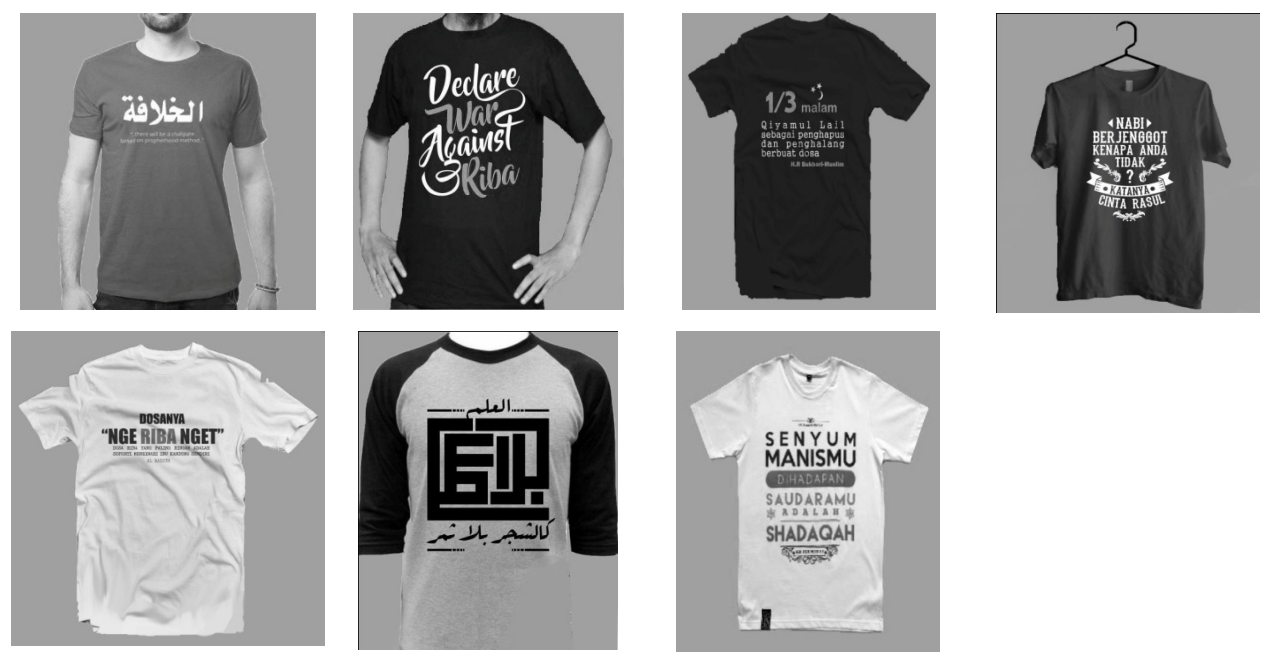

Gambar 4

Lebihjauh, beberapa kaosjuga tampak mengampanyekan semangat meneladani sikap Rasul dari berbagai aspek, mulai dari politik, ekonomi, akhlak, keutamaan menuntut ilmu sampai pada persoalan jenggot. Seperti dalam persoalan politik yang terwakili dengan kaos yang bernada ajakan penegakkan khilafah dengan ungkapan "al-khilafah: there will be a caliphate based on prophet method" yang berarti akan ada kekhilafahan berdasarkan atas metode nabi. Atau dalam persoalan ekonomi untuk membersihkan sekaligus memerangi riba dalam kalimat "declare war against riba", artinya pernyataan perang melawan riba. Juga ajakan untuk shalat malam dengan mengutip hadis yang diriwayatkan Bukhari dan Muslim, meski tidak lengkap, tentang keutamaan shalat lail pada sepertiga malam sebagai penghapus dan penghalang berbuat dosa. Demikian pula mengenai kritik terhadap laki-laki yang tidak mau atau enggan memelihara jenggot dalam ungkapan "Nabi berjenggot, kenapa anda tidak? katanya cinta rasul". 
INJECT: Interdisciplinary Journal of Communication, Vol.2, No.2, Des. 2017: h. 247-274

\section{Hadis pada Kaos: Sebuah Interpretasi Makna Simbolik}

Dalam mengkaji jenis-jenis tulisan dan simbol pada kaos-kaos di atas, penulis menggunakan pendekatan semiotika Charles Sanders Peirce, seorang filsuf gaek aliran pragmatik Amerika. Istilah semiotika dimunculkan pada akhir abad ke-19, yang merujuk pada doktrin formal tentang tanda-tanda. Sedangkan yang menjadi dasar dari semiotika adalah konsep tentang tanda; tak hanya bahasa dan sistem komunikasi yang tersusun oleh tanda-tanda, melainkan dunia itu sendiri pun-sejauh terkait dengan pikiran manusia-seluruhya terdiri atas tanda-tanda. Karena jika tidak begitu manusia tidak bisa menjalin hubungan dengan realitas (Sobur, 2009:13). Jadi, secara lebih tegas dapat dikatakan bahwa semiotika merupakan ilmu yang mempelajari tentang makna dari tandatanda. Tanda (representament) yaitu sesuatu yang dapat mewakili sesuatu yang lain dalam batas-batas tertentu.

Adapun berdasarkan objeknya, Peirce membagi tanda dalam tiga komponen; icon (ikon), index (indeks), dan symbol (simbol). Ikon adalah tanda yang hubungan antara penanda dan petandanya bersifat bersamaan bentuk alamiah. Atau, ikon adalah hubungan antara tanda dan objek atau acuan yang bersifat kemiripan, misalnya, potret dan peta. Indeks adalah tanda yang menunjukkan adanya hubungan alamiah antara tanda dan petanda yang bersifat kausal atau hubungan sebab akibat, atau tanda yang langsung mengacu pada kenyataan, misalnya asap sebagai tanda adanya api. Kemudian, simbol yaitu tanda yang menunjukkan hubungan alamiah antara penanda dengan petandanya, yang dapat mengacu ke denotatum melalui konvensi (Sobur, 2009:13). Dengan begitu, hubungan antara simbol sebagai penanda dengan sesuatu yang ditandakan atau petanda sifatnya konvensional. Dengan konvensi itu pula masyarakat pemakainya menafsirkan ciri hubungan antara simbol dengan objek yang diacu sekaligus menafsirkan maknanya (Sobur, 2009:13). 
Hadis Nabi saw yang tertera pada kaos-kaos menjadi media komunikasi untuk mengirimkan pesan. Pesan diproduksi dalam ruang lingkup sosial tertentu agar tersampaikan kepada pembaca. Sehingga terjadi pertukaran makna yang terjadi di balik simbol-simbol yang tersembunyi. Ketika pesan tersebut keluar maka penerima pesan memiliki kebebasan untuk menginterpretasikannya. Akan tetapi, kebebasan makna yang lahir dari bentuk komunikasi bergantung pada si penerima pesan. Boleh jadi sistem budaya dan pengetahuan sangat berpengaruh bagaimana penerima menangkap pesan yang tersurat maupun tersirat. Pengalaman dan pengetahuan pengirim dan penerima pesan bisa berbeda. Ketidaksamaan ini pun akan memunculkan makna yang juga berbeda antara pengirim dan penerima. Makna akan menjadi pengertian yang cair bergantung pada ruang budaya di mana pesan diproduksi (Brata, 2010:1).

Semantara itu, simbol dalam pandangan Peirce dalam istilah seharihari lazim disebut dengan kata (word), nama (name) dan label (lable). Simbol memiliki hubungan asosiatif dengan gagasan atau referensi serta referen atau dunia acuan. Sebagaimana dalam wawasan Peirce hubungan ketiga butir tersebut bersifat konvensional. Mengacu pada pendapatnya bahwa tanda dan pemaknaannya bukan struktur melainkan suatu proses kognitif yang disebutnya semiosis. Jadi semiosis adalah proses pemaknaan dan penafsiran tanda melalui tiga tahapan. Tahap pertama adalah pencerapan aspek representamen tanda (pertama melalui pancaindra), tahap kedua mengaitkan secara spontan representamen dengan pengalaman dalam kognisi manusia yang memaknai representamen itu (disebut object), dan ketiga menafsirkan object sesuai dengan keinginannya. Tahap ketiga ini disebut interpretant (Benny, 2014:8). Dengan demikian, istilah makna simbolik dalam artikel ini yaitu maksud atau makna yang terkandung dalam suatu simbol atau perlambang terkait dengan hadis pada kaos. Simbol-simbol yang memiliki makna yang dimaksud yaitu konten tulisan atau kalimat-kalimat hadis, bentuk tulisan, dan simbol-simbol sebagai petanda dalam tulisan. 
Simbol tidak dapat disikapi secara isolatif, terpisah dari hubungan asosiatifnya dengan simbol lainnya. Walaupun demikian berbeda dengan bunyi, simbol telah memiliki kesatuan bentuk dan makna. Berbeda pula dengan tanda (sign), simbol merupakan kata atau sesuatu yang bisa di analogikan sebagai kata yang telah berkait dengan (1) penafsiran pemakai, (2) kaidah pemakaian sesuai dengan jenis wacananya; dan (3) kreasi pemberian makna sesuai dengan intensi pemakainya. Simbol yang ada dalam dan berkaitan dengan ketiga butir tersebut disebut bentuk simbolik.(Sobur, tt:156).

Jika diamati secara seksama, akan ditemukan kombinasi simbolik yang menyimpan makna dari setiap hadis yang dituliskan pada kaos. Dalam hal ini, hadis pada kaos merupakan bentuk simbol dikarenakan adanya hubungan kata dengan dunia acuannya berdasarkan kaidah kebahasaannya. Kaidah kebahasaan itu secara artifisial dinyatakan dan ditentukan berdasarkan konvensi masyarakat pemakainya.

Tulisan "malu itu sebagian dari iman" menyiratkan satu tanda yang mengirimkan pesan tentang sikap malu adalah sebagian dari iman. Berdasarkan interpretant, kalimat tersebut masuk dalam klasifikasi Pierce jenis rheme, tanda yang memungkinkan orang menafsirkan berdasarkan pilihan. Dalam konteks tanda, maka kalimat tersebut menjadi ikon dari rasa malu yang disuarakan, diwujudkan dalam rasa malu itu, sehingga seseorang akan dianggap masih memiliki iman. Sementara indeks dari kalimat tersebut disebabkan banyaknya perbuatan buruk dan nista yang dilakukan secara terang-terangan, atau absennya rasa malu pada diri seseorang. Dan barisan kalimat tersebut merupakan simbol untuk merespons keadaan, di mana perasaan malu menjadi barang langka di zaman ini. Malu berbuat keburukan, malu membuka aurat, malu melakukan kenistaan, malu mencuri dan mengambil hak orang lain, dan lain sebagainya.

Ini juga merupakan bentuk hubungan asosiatif dengan gagasan referensial dan dunia acuannya. Dalam arti, lahir dari keprihatinannya 
atas mahalnya rasa malu, baik secara artifisial maupun alamiah. Pesan pada kaos tersebut pun menyiratkan identitas sosial bagi pemakai dan pembaca. Bagi pemakai ia harus terus menjaga sikap agar tidak serampangan dalam perbuatan, sedangkan bagi pembaca akan menjadi pengingat ketika objek tertangkap dan menjadi kesadaran intrinsik dari kepribadiannya.

Adapun pada kalimat "shalatlah pada waktunya" di sini memperlihatkan ikon bulat seperti jam; bentuk bulat, beberapa ruas garis seperti jarum jam yang menunjukkan waktu, yang merepresentasikan sesuatu secara alamiah. Bisa jadi ini merupakan tanggapan atas ketidakteraturan masyarakat dalam memerhatikan waktu-waktu shalat, dan ini sekaligus menjadi indeks dari rangkaian kata tersebut. Lebih dari itu, tulisan itu memunculkan interpretasi bahwa si pemakai selalu shalat tepat waktu, atau setidaknya sebagai 'warn' untuk menjaga waktu-waktu shalat. Bisa juga ia mengirim peringatan kepada pembaca agar melaksanakan shalat tepat waktu.

Simbol dalam font atau bentuk tulisan dapat pula diasumsikan dengan tegas-lurus tanpa kelokan. Tulisan pada kaos ini menggunakan font jenis avantgarde, tegak-lurus tanpa lengkung pada sisinya. Simbolisasi font ini memiliki makna ketegasan yang berkaitan dengan nilai tersirat pada kalimat itu sendiri, yang berarti adanya asosiasi alamiah antara font, bentuk jam, dan rentetan kalimat. Bahwa shalat harus disiplin dalam waktu pelaksanaannya. Dengan kata lain, setiap muslim harus senantiasa memerhatikan waktu shalat dan harus tegas dalam menjalakannya. Tidak boleh diundur, harus tepat waktu, apalagi sampai menembus waktu shalat berikutnya. Hal ini sebagaimana beberapa penelitian yang mengatakan bahwa semakin tinggi kedisiplinan melaksanakan shalat wajib, akan diikuti semakin rendahnya prokrastinasi (menunda-nunda suatu pekerjaan) dalam kinerja, sebaliknya semakin rendah kedisiplinan melaksanakan shalat wajib, akan diikuti semakin tingginya prokrastinasi dalam 
INJECT: Interdisciplinary Journal of Communication, Vol.2, No.2, Des. 2017: h. 247-274

kinerja. (Siswanto, 2013:1).

Pemaknaan simbolik lebih luas bisa ditemukan dalam kaos yang bertuliskan, "my prayer, my sacrifice, life and death are for allah lord of the worlds" (Sesungguhnya shalatku, ibadahku, hidup dan matiku hanya untuk Allah, Tuhan semesta alam) kalimat ini merupakan penggalan dari doa iftitah yang dibaca setelah takbiratul ihram. Dalam sebuah riwayat dikatakan bahwa ini adalah penggalan dari doa iftitah yang sering diucapkan Rasulullah setelah takbiratul ihram (Muslim, tt:169). Dan ini merupakan pernyataan kepasrahan dan penyerahan total atas shalat atau ibadah lainnya, pengorbanan, kehidupan dan kematian hanya kepada Allah swt.

Pada kaos tersebut tidak hanya tulisan, melainkan dilengkapi dengan siluet yang mengilustrasikan perjalanan hidup manusia. Tulisan dan gambar di sini menunjukkan ikon sebagai tanda, meskipun hanya dalam bentuk ilustrasi. Sedangkan gambar perjalanan menjadi indeks dari kalimat berbahasa inggris tersebut. Dalam arti, indek kematian yang disimbolkan dengan kotak yang menyerupai bentuk kuburan terjadi karena adanya Allah sang pemilik sejati, di mana semua yang dilakukan dan dimiliki manusia yang hidup akan berpulang kepada-Nya. Atau, kematian mencirikan adanya kehidupan. Dengan perspektif terbalik, masa tua didahului dengan paruh baya; didahului masa muda; didahului dengan masa kanak-kanak; didahului masa balita, dan seterusnya.

Kalimat dan ilustrasi pada kaos ini saling berkaitan. Simbol yang terangkum dalam tulisan dan ilustrasi ini mengirimkan pesan berupa peringatan kepada pembaca agar senantiasa menyadari asal-muasal dirinya. Kemungkinan makna simbolik gambar dan tulisan tersebut menggambarkan pengalaman pemakainya, seakan si pemakai telah mengalami titik kulminasi dalam kehidupannya, hingga membawanya pada kesadaran keagamaan (religious consciousness) yang berpijak pada kepasrahan diri secara total. Si pemakai berusaha untuk selalu diingatkan dengan tulisan di kaosnya sendiri, dan ini merupakan wacana fundamental dalam 
kesadaran pemakainya.

Demikian pula berbagai kemungkinan bisa terjadi dalam konteks relasi sosial. Ketika memakai kaos ini seseorang ingin dianggap sedang "sadar" akan hakikat hidupnya. Seakan ia ingin mengklaim dirinya dengan ungkapan "aku sedang sadar". Atau ia sedang ingin selalu ingat akan asal muasal dan tujuan hidupnya. Sehingga pemakaian kaos ini menjadi terapi entah setelah melepasnya, karena kaos akan merepresentasikan pribadi pemakainya. Maka di sinilah makna simbolik dari keseluruhan gambar dan tulisan pada kaos tersebut.

Selanjutnya, kaos lainnya mencirikan sebuah jargon "back to the quran and Sunnah shahihah". Pun demikian, dalam kaos lain juga mengirimkan pesan senada dalam ungkapan "follow the Quran and Sunnah and you get jannah". Pada dasarnya, kedua jargon tersebut memiliki inti yang sama, yaitu kembali kepada al-Quran dan Sunnah Nabi saw. Memang, sekilas kedua tulisan ini sebuah kampanye yang sangat efektif dan bagus untuk menyadarkan setiap bahwa keduanya merupakan warisan Nabi yang sangat berharga. Terlebih ada legitimasi yang menjadi sumber pengambilan tulisan tersebut dari hadis Nabi yang artinya, Rasulullah saw bersabda, "aku tinggalkan kepada kalian dua warisan. Kalau kalian berpegang teguh kepadanya kalian tidak akan tersesat, yaitu kitab Allah dan sunnah Rasulullah saw". Namun, lagi-lagi jika hanya dipahami melalui teks literalnya akan sangat problematik.(Muwatha, tt: 1395).

Adapun yang menjadi ikon dari tulisan tersebut adalah mengembalikan setiap permasalahan kepada al-Quran dan Sunnah ditandai dengan hadirnya tulisan. Ia menjadi objek acuan yang lazim yang menjadi ciri utama kembali kepada kedua sumber utama umat Islam. Hal ini dipicu atas keinginan untuk memurnikan ajaran Islam sesuai al-Quran dan Sunnah. Sementara itu, menurut penulis, dalam menyematkan logo atau typeface yang tertera menyerupai bentuk tulisan dari salah satu produsen rokok. Bentuk font berwarna putih dengan membubuhkan type 
yang berbeda dan warna merah pada huruf A. Di sini ada dua hal yang saling kontradiksi. Di satu sisi, ia menyuarakan untuk kembali kepada al-Quran dan Sunnah dalam jargonnya. Atau, siapa saja yang mengikuti al-Quran dan Sunnah akan memperoleh surga. Namun di sisi lain, justru menampilkan logo atau typeface yang dimiliki brand produk rokok ternama di Indonesia, yang konon rokok diharamkan bagi pengusung jargon tersebut.

Tidak terlalu sulit untuk mendefinisikan typeface yang digunakan. Ada dua kemungkinan yang bisa terbaca dari pengambilan dengan pola semacam itu. Pertama, disainer tidak memahami korelasi kontradiktif antara yang ditulisankan dan makna typeface tersebut. Asal menarik dan eyecathcing maka akan langsung dimodifikasi. Kedua, untuk pengalihan dari logo produk rokok yang nyata-nyata ditentangnya guna menarik kaum muda yang gandrung dengan produk tersebut. Demikian juga si pemakai seakan ingin menunjukkan identitas dirinya sebagai pengikut sunnah. Alih-alih sekadar ikut-ikutan trend islamis yang sedang marak di negara ini, si pemakai bisa jadi tidak memahami maksud dalam tulisan tersebut.

Selain itu, jika diamati lebih dalam, jargon tersebut hendak menyadarkan para pembacanya untuk kembali kepada al-Quran dan Sunnah. Dengan kembali kepada keduanya maka akan ditemukan keseragaman pemahaman dan tidak lagi ada perbedaan. Akan tetapi, dengan kembali kepada keduanya pada kenyataannya tidak menjamin adanya keseragaman. Karena meskipun kepada sumber yang sama namun metode pengambilan hukumnya (istidlal) berbeda maka ditemukan keputusan (istinbath) hukum yang berbeda. Mereka sama-sama mengambil sumber hukum yang sama, tapi produk hukum yang dikeluarkan akan berbeda. Jadi tidak bisa terjadi klaim dengan hanya mengandalkan jargon tersebut. Dengan kata lain, kembali kepada al-Quran dan Sunnah tidak semata-mata kembali tanpa dasar keilmuan yang kuat. Lagi pula para 
ulama sebagai salaf ash-shalih harus menjadi pertimbangan yang tidak bisa diabaikan karena mereka telah merumuskan ragam penafsiran dan mengeluarkan produk hukum yang juga merujuk kepada keduanya.

Hal di atas mengingatkan penulis atas ungkapan almarhum Cak Nur yang mengatakan:

Kembali kepada al-Quran dan as-Sunnah dalam pelaksanaan praktisnya ternyata sangat tidak mudah. Bahkan yang sudah terjadi, dalil itu, sebegitu jauh, baru menghasilkan reformasi atau mungkin-pemurnian hal-hal yang sesungguhnya sangat bersifat pinggiran (peripheral)."(Madjid, 1999:391).

Lebih lanjut ia menegaskan:

Meskipun hal serupa itu sangat penting bagi banyak kalangan sebagian kaum Muslim melihat dan mendapati di situ terletak inti agama dan rasa keagamaan mereka, namun sebetulnya sahamnya dalam usaha umat Islam menemukan peran kesejarahannya kembali tersebut di atas paling untung marginal saja, jika bukannya tidak ada sama sekali. Kalau masalah ini harus diungkapkan dalam sebuah jargon, barangkali yang paling tepat ialah pesan almarhum Bung Karno, salah seorang Bapak Bangsa Indonesia, agar kita berusaha menangkap-api Islam, dan bukanabunya. Pembahasan ini adalah dalam rangka mencoba menangkap-api itu, betapa pun kecilnya kemungkinan hasil yang didapatkan".

Hadis Nabi saw harus menjadi landasan utama dalam menjalankan Islam secara kaffah. Namun yang lebih utama adalah bagaimana para pengikutnya mampu menangkap spirit terdalam dari pesan Nabi tersebut. Sebagaimana persoalan memelihara jenggot seperti pertanyaan menjebak dalam salah satu kaos, "Nabi berjenggot, kenapa anda tidak? katanya cinta Rasul". Pertanyaan ini merupakan bentuk logical fallacy yang terkesan menjebak, dan tentunya si penanya mengharapkan sebuah jawaban, "kalau anda cinta Rasul, maka peliharalah jenggot". Seakan memberikan ilustrasi tolak ukur kecintaan kepada Nabi dengan memelihara jenggot. Semudah itukah? 
Kaos dengan tulisan tersebut merepresentasikan wajah manusia. Dan ini merupakan ikon yang identik. Berbentuk oval, dengan "tanda tanya" yang mewakili hidung, kemudian jenggot dan ornamen yang menyerupai jenggot di bagian paling bawah. Selain itu, bentuk font lagilagi identik dengan jenis font yang saat ini marak digunakan oleh beberapa Barber Shop (jasa pangkas rambut pria), dengan jenis retro-vintage. Tentu saja keseluruhan ini menjadi simbol yang memiliki hubungan asosiatif dengan referensi tempat memangkas rambut, merapikan kumis, dan memanjangkan jenggot bagi pria; Barber Shop. Kaos dengan tulisan seperti ini tentu saja ingin menunjukkan identitas personal pemakainyayang kemungkinan besar memelihara jenggotnya, bahkan menjadi klaim status pribadinya yang mencintai Rasul dengan memelihara jenggot.

Menurut hemat penulis, sebagaimana disebutkan diatas, pertanyaan ini masuk kategori logical fallacy ad hominem atau kesalahan dalam berpikir dalam bentuk menyerang kepribadian daripada argumen yang seharusnya diperdebatkan. Dalam arti, titik perdebatan tidak mendasarkan pada argumen yang nyata, melainkan lebih menyerang kepribadian. Dengan ungkapan lain, adanya jenggot tidak berarti membuktikan kecintaan kepada Rasul. Atau sebaliknya, ketiadaan jenggot tidak bisa menjadi dasar ketidak cintaan seseorang kepada Rasul.

Setidaknya ada dua indeks yang bisa terbaca dalam konteks pertanyaan terseut. Pertama, ketiadaan jenggot pada kebanyakan laki-laki karena rasa malu akan tampil lebih tua dari usianya, sehingga melahirkan desain dalam bentuk tulisan yang mempertanyakan keseriusan dalam mencintai Nabi dengan tolok ukur yang salah. Kedua, kebanyakan lakilaki memotong jenggotnya karena banyaknya stigma negatif yang saat ini disematkan secara tidak adil terhadap orang-orang yang ingin mengikuti sunnah Nabi-kalau itu dianggap sunnah-dalam memelihara jenggot dan memotong kumis, seperti sabda Nabi, sehingga mereka enggan mengikutinya. 
Apabila ditelaah lebih lanjut, hadis ini secara lengkap memiliki arti, "Dari Ibnu Umar ra, Rasulullah saw. bersabda: Selisihilah kaum musyrikin, biarkanlah jenggot kalian panjang, dan potong tipislah kumis kalian". (Bukhori, $\mathrm{tt}$ :5892) Ini dipahami oleh sebagian umat Islam sebagai perintah untuk memelihara kumis dengan memangkas ujungnya dan memanjangkan jenggot. Mereka memandang bahwa itu menjadi bukti cinta Rasul. Yang demikian ini merupakan pemahaman tekstual karena hanya melihat teks tanpa memerhatikan konteks budaya, sosial, dan gegrafis di mana hadis tersebut lahir.

Mengutip penjelasan Syuhudi Ismail bahwa perintah Nabi tersebut memang relevan untuk orang-orang Arab, Pakistan, dan lain-lain yang secara alamiah dikaruniai rambut yang subur, termasuk di bagian kumis dan jenggot. Tingkat kesuburan dan ketebalan rambut milik orang-orang Indonesia tidak sama dengan milik orang Arab. Tidak sedikit orang Indonesia yang jarang memiliki jenggot (Ismail, 1994:68). Maka dari itu, hadis ini harus dipahami secara kontekstual di mana dan pada realitas serta situasi yang bagaimana hadis tersebut lahir. Hadis harus dihubungkan dengan kontekstual. Karena kandungan hadis ada yang bersifat universal, temporal, dan lokal.

Seperti ungkapan Umberto Eco "I speak through my cloth" (aku berbicara lewat pakaianku), hadis-hadis dalam kaos-kaos di atas secara keseluruhan menyimpan makna simbolik yang merepresentasikan pribadi si pemakai. Ia mengirimkan pesan kebaikan kepada komunikan tentang nilai-nilai yang ada dalam sebuah hadis. Hal tersebut tidak bisa lepas dari relasi yang dibangun dengan lingkungan sosialnya. Tidak jarang justru bernilai kontradiksi dan ambigu dengan pemakainya sendiri. Namunsebagaimana tulisan Antariskan-betapa pun klaim atas identitas atau status dalam kaos oblong ini bersifat ambigu, dalam terminologi Umberto Eco (1979), representasinya selalu bersifat undercoded, ia berhubungan secara synecdochical (satu bagian dari kaos mewakili keseluruhan pribadi 
seseorang) dengan pengalaman, relasi sosial, nilai, atau status yang diklaim secara eksplisit atau implisit oleh pemakainya. Pesan yang disampaikan dalam kaos bukanlah sekedar tentang tempat, kelompok, atau bisnis, tetapi klaim atas status pemakainya.

\section{Simpulan}

Pada akhirnya, dengan makna simbolik yang merepresentasikan pribadi si pemakai, kaos hadis dapat menjadi alat komunikasi sekaligus media dakwah instan yang sangat efektif untuk mengingatkan seseorang akan nilai-nilai yang dibawanya. Setidaknya, setiap orang yang membaca sekilas akan tersadarkan akan kebaikan yang tertera. Terlepas mereka mau mengikuti atau tidak itu menjadi hak para pembaca sebagai penafsirnya. Makna simbolik yang ada pun tidak dapat disikapi secara isolatif, terpisah dari hubungan asosiatifnya dengan simbol lainnya. Ia merupakan bentuk kata yang telah berkait dengan penafsiran pemakai, kaidah pemakaian sesuai dengan jenis wacananya; dan, kreasi pemberian makna sesuai dengan intensi pemakainya.

\section{Daftar Pustaka}

Amin, Kamaruddin. 2009. Menguji Kembali Keakuratan Metode Kritik Hadis. Jakarta: Hikmah.

Antariksa. "Menjadi Modern dengan Kaos". dalam http://kunci.or.id/esai/ misc/antariksa_kaos.htm.

Brata, Dion Dewa. "Fashion Sebagai Strategi Simbolik Komunikasi Non-Verbal" dalam Junal Ilmu Komunikasi Universitas Multimedia Nusantara, Vol. II, No. 1, Juni 2010.

Cook, Michael. 2012. The Opponents of the Writing of Tradition in Early Islam (Oposisi Penulisan Hadis di Masa Awal), terj. Ali Masrur Abdul Ghaffar. Bandung: Marja. 
2014. Social Media Security: Leveraging Social Networking

While Mitigating Risk. Waltham: Syngrees.

Fathroen, Dimaz, "Empat Langkah Mudah Cek Berita Hoax atau Bukan" dalam http://www.tagar.id/empat-langkah-mudah-cekberita-hoax-atau-bukan/6/ akses Selasa, 5 Desember 2017

Gilster,P. 1997. Digital Literacy. New York.

Hoed, Benny H. 2014. Semiotik dan Dinamika Sosial Budaya. Depok: Komunitas Bambu.

Ismail, Syuhudi. 1995. Hadis Nabi Menurut Pembela, Pengingkar, dan Pemalsunya. Jakarta: Gema Insani. . 1994. Hadis Nabi yang Tekstual dan Kontekstual; Telaah Ma'an al-Hadits tentang Ajaran Islam yang Universal, Temporal, dan Lokal. Jakarta: Bulan Bintang.

Katsir, Ibnu, Tafsir al-Quran al-Adzim, juz. V, hlm. 432, dalam dalam almaktabah asy-Syamilah, v.2.11.

Madjid, Nurcholis. 1999. Islam Doktrindan Peradaban. Jakarta: Paramadina. Riyana, Rudi Susilana dan Cepi. 2009. Media Pembelajaran: Hakikat, Pengembangan, Pemanfaatan, dan Penilaian. Bandung: CV. Wacana Prima.

Sanusi, Muhammad Husein. "Ustadz Abdul Somad, Contoh Terbaik Dakwah di Era Digital." Dalam Akun Facebook. Akses Senin, 4 Desember 2017

Siswanto, Fevi Zanfiana, "Hubungan Antara Kedisiplinan Melaksanakan Sholat Wajib Dengan Prokrastinasi Akademik Pada Mahasiswa di Fakultas Farmasi Universitas Ahmad Dahlan" dalam Emphaty: Jurnal Fakultas Psikologi Universitas Ahmad Dahlan. Vol. 2, no. 1, 2013.

Sobur, Alex. 2009. Semiotika Komunikasi. Bandung: Remaja Rosdakarya. Sonnaonline.com 
INJECT: Interdisciplinary Journal of Communication, Vol.2, No.2, Des. 2017: h. 247-274

Suryadilaga, Muhammad Alfatih. "Kajian Hadis di Era Global" dalam Esensia: Jurnal Ilmu-Ilmu Ushuluddin, vol.15, no. 2, September 2014. Suyuti, Jalal ad-Din. 1972. Tadhrib ar-Rawi fi Syarh Taqrib an-Nawawi, Madinah: tp. 